\title{
PENGARUH INOKULASI Lactobacillus plantarum DAN Saccharomyces cerevisiae TERHADAP FERMENTASI DAN KECERNAAN IN VITRO SILASE KULIT BUAH KAKAO
}

\section{THE EFFECT OF Lactobacillus plantarum AND Saccharomyces cerevisiae CULTURE ADDITION PRIOR TO ENSILAGE ON IN VITRO FERMENTATION AND DIGESTIBILITY OF COCOA POD SILAGE}

\author{
Muhammad Askari Zakariah"1*, Ristianto Utomo ${ }^{2}$, dan Zaenal Bachruddin ${ }^{2}$ \\ ${ }^{1}$ STAI Al-Mawaddah Warohmah Kolaka, Sulawesi Tenggara, 93516 \\ ${ }^{2}$ Fakultas Peternakan, Universitas Gadjah Mada, Yogyakarta, 55281
}

Submitted: 2 November 2015., Accepted: 21 May 2016

\section{INTISARI}

Penelitian ini bertujuan untuk mengetahui pengaruh inokulasi campuran Lactobacillus plantarum dan Saccharomycess cerevisiae pada silase kulit buah kakao (KBK) terhadap produksi gas, fermentasi rumen dan kecernaan in vitro. Penelitian ini menggunakan empat macam perlakuan, yaitu: silase KBK tanpa penambahan inokulan sebagai kontrol $(\mathrm{K})$, kontrol dengan penambahan L. plantarum (KLp), kontrol dengan penambahan S. cerevisiae (KSc), kontrol dengan penambahan campuran L. plantarum dan S. cerevisiae $(\mathrm{KLp}+\mathrm{Sc})$ sebanyak $0,1 \% \mathrm{BK}$, masing-masing perlakuan ditambahkan tepung gaplek. Setiap perlakuan diberikan replikasi tiga kali dan diperam selama 21 hari. Parameter yang diamati meliputi: produksi gas, parameter fermentasi rumen, dan kecernaan in vitro. Data yang diperoleh dianalisis dengan Analysis of variance pola searah dan apabila terdapat perbedaan yang nyata dilanjutkan dengan uji Duncan new Multiple Range Test. Hasil penelitian menunjukkan bahwa inokulasi campuran L. plantarum dan $S$. cerevisiae meningkatkan $(P<0,05)$ kualitas silase KBK dengan menurunkan fraksi serat dan meningkatkan fraksi BETN, meningkatkan laju degradasi, meningkatkan degradasi teori, menurunkan $\mathrm{pH}$ rumen, menurunkan propionate dan meningkatkan produksi asam butirat, namun tidak mempengaruhi rasio asetat terhadap propionate, sintesis mikroba, maupun nilai kecernaan silase KBK.

(Kata kunci: Kulit buah kakao, Fermentasi rumen, Kecernaan in vitro, Lactobacillus plantarum, Saccharomycess cerevisiae, Silase)

\section{ABSTRACT}

The objective of this study was to identify the effect of L. plantarum and S. cerevisiae mixed culture inoculation into cocoa pods silage on chemical composition and in vitro digestibility. The four treatments were: $1 \mathrm{~kg}$ freshly harvested cocoa pods without inoculants as control $(K) ; K+L$. plantarum $(K L p) ; K+S$. cerevisiae (KSc); and $K+L$. plantarum and S. cerevisiae mixture $(K L p+S c) 0.1 \%$ dry matter, Cassava meal were added in all treatments. Each treatment was replicated 3 times, and then fermented for 21 days. Parameters observed in current study were gas test production, ruminal fermentation parameter, and in vitro digestibility. The collected data were analyzed by one-way analysis of variance and followed by Duncan's new Multiple Range Test for data with significant differences. Result showed that the mixed culture $L p+S c$ inoculation increased $(P<0.05)$ chemical quality of cocoa pods by reducing fibre fraction and increase NFE contents, increased degradation rate, degradation theory, reduced rumen $\mathrm{pH}$, and propionate acid production, without affecting acetate to propionate ratio, microbial protein synthesis, and digestibility of cocoa pod silage.

(Key word: Cocoa pod, In vitro digestibility, Lactobacillus plantarum, Ruminal Fermentation, Saccharomyces cerevisiae, Silage)

*korespondensi (coresponding author):

Telp. +62 85729816427

E-mail: askarizakariah@yahoo.com 


\section{Pendahuluan}

Kondisi iklim di Indonesia menjadikan adanya fluktuasi pakan hijauan makanan ternak yang dapat berakibat buruk pada produktivitas ternak ruminansia. Penggunaan hasil sisa perkebunan sebagai pakan berserat untuk mensubtitusi rumput menjadi salah satu alternatif. Perkebunan kakao di Indonesia merupakan salah satu perkebunan yang memiliki area yang cukup luas. Perkebunan kakao menghasilkan limbah dalam bentuk padat yang disebut kulit buah kakao (KBK). Zain (2009) melaporkan bahwa KBK mengandung bahan kering $17,2 \%$, bahan organik $81,2 \%$, protein kasar $9,07 \%$, neutral detergent fiber $73,9 \%$, acid detergent fiber $58,98 \%$, lignin $20,15 \%$, dan selulosa $38,65 \%$.

Kulit buah kakao memiliki kandungan air yang cukup tinggi sehingga dalam jangka waktu tertentu akan membusuk. Teknologi silase merupakan salah satu alternatif untuk dapat mengawetkan dan meningkatkan kualitas KBK. Penambahan inokulan digunakan untuk meningkatkan kualitas silase. Inokulan yang biasa digunakan adalah bakteri asam laktat. $L$. plantarum dapat dipakai sebagai bahan aditif silase untuk memodifikasi fermentasi silase. Inokulan Lactobacillus plantarum merupakan salah satu jenis bakteri asam laktat yang memproduksi asam laktat pada kondisi anaerob. Asam laktat yang diproduksi akan menurunkan derajat keasaman tumpukan silase. $\mathrm{pH}$ yang rendah dapat menghambat pertumbuhan mikrobia pembusuk dan patogen sehingga menghindari penurunan kualitas silase. McDonald et al. (2002) menyatakan bahwa selama proses fermentasi silase terjadi hidrolisis hemiselulosa menjadi gula sederhana yang dapat digunakan oleh $L$. plantarum untuk dikonversi menjadi asam laktat.

Inokulasi Saccharomycess cerevisiae sebagai agen pengguna oksigen pada fase aerob, diharapkan menjadikan fase anaerob optimum. Inokulan S. cerevisiae selama fase aerob akan melakukan metabolisme. Inokulan S. cerevisiae dapat menghasilkan oxylpins sebagai zat antimikrobia yang dapat menghambat pertumbuhan mikrobia pembusuk dan patogen selama fase aerob. Oksigen yang habis digunakan oleh $S$. cerevisiae maka akan terganti menjadi fase anaerob yang menstimulasi pertumbuhan L. plantarum untuk menghasilkan asam laktat.
Inokulasi campuran L. plantarum dan S. cerevisiae pada pembuatan silase akan mempengaruhi komposisi kimia silase KBK. Perubahan pada komposisi kimia silase KBK akan mempengaruhi proses fermentasi di dalam rumen dan kecernaan. Penelitian ini bertujuan untuk mengetahui pengaruh inokulasi campuran $L$. plantarum dan $S$. cerevisiae pada silase KBK terhadap total produksi gas, parameter fermentasi rumen, dan kecernaan in vitro.

\section{Materi dan Metode}

Penelitian dilaksanakan di Laboratorium Biokimia Nutrisi Fakultas Peternakan, UGM, Yogyakarta. Alat yang digunakan adalah timbangan kapasitas $10 \mathrm{~kg}$ dengan kepekaan $0,1 \mathrm{~kg}$, timbangan analitik dengan kepekaaan 0,0001 $\mathrm{g}$, sealer dan vacuum merk Power Pack, pH meter, oven, mesin giling dengan diameter lubang saringan $1 \mathrm{~mm}$, seperangkat peralatan analisis amonia, gas kromatografi, protein mikrobia. Bahan yang digunakan dalam penelitian ini berupa kulit buah kakao segar, L. plantarum, $S$. cerevisiae, tepung gaplek, air, bahan kimia untuk analisis produksi gas tes, kadar amonia, VFA, protein mikrobia, dan kecernaan in vitro.

Proses pembuatan silase skala laboratorium dilakukan pada ruang steril. Kulit buah kakao segar dikumpulkan dari perkebunan rakyat Kabupaten Gunungkidul. Kulit buah kakao kemudian dicacah dengan ukuran $2 \times 1 \mathrm{~cm}$ lalu diangin-anginkan selama 10 jam. Dua spesies inokulan L. plantarum yang ditumbuhkan pada medium man rogosa and sharpes (MRS) broth, sedangkan inokulan S. cerevisiae ditumbuhkan pada medium malt extract (ME) broth. Ruang fermentasi disemprot desinfektan, peralatan disterilkan dengan alkohol 90\%. Kulit buah kakao difermentasi dalam kantong plastik warna putih dengan kapasitas $2 \mathrm{~kg}$. Satu $\mathrm{kg}$ KBK (45\% BK) dan $200 \mathrm{~g}$ tepung gaplek (55\% BK) digunakan untuk setiap kantong plastik. Satu kg KBK dan $200 \mathrm{~g}$ tepung gaplek dicampur secara merata dengan inokulan $L$. plantarum, S. cerevisiae dan campurannya (1:1) sebanyak 0,1\% BK. Lama fermentasi 21 hari. Analisis komposisi silase KBK tersaji pada Tabel 1.

Penelitian ini memiliki rancangan penelitian yang terdiri dari empat perlakuan. Perlakuan tersebut adalah: KBK + tepung gaplek + aquades sebagai kontrol (K0), $\mathrm{KO}+$ L. plantarum (KLp), K0 + S. cerevisiae (KSc), 
$\mathrm{KO}+$ L. plantarum + S. cerevisiae $(\mathrm{KLp}+\mathrm{Sc})$. Sampel dianalisis total produksi gas, parameter fermentasi $(\mathrm{pH}$, amonia, VFA, protein mikrobia rumen), dan kecernaan in vitro. Data yang diperoleh dianalisis dengan analisis variansi dari Rancangan Acak Lengkap pola searah. Perbedaan rerata antar perlakuan dianalisis dengan Duncan's new Multiple Range Test (Astuti, 2007). Semua perhitungan analisis statistik dilakukan dengan bantuan software personal komputer Statistical Product and Service Solution versi 16.0 (Soleh, 2005).

\section{Hasil dan Pembahasan}

\section{Kinetika produksi gas}

Hasil uji produksi gas, fraksi pakan terdegradasi optimum, laju degradasi pakan dan degradasi teori silase KBK dengan penambahan dan tanpa inokulan tersaji pada Tabel 2.

Hasil penilitian menujukkan bahwa produksi gas terus meningkat hingga jam ke72. Laju produksi gas cendrung tinggi mulai jam ke-6 menuju jam ke-12 dan lambat mulai jam ke-48 (Grafik 1).

Fermentasi nutrien yang terjadi di dalam rumen akan menghasilkan gas, bahan organik yang didegradasi oleh mikrobia rumen merupakan sumber utama dihasilkannya gas, semakin besar bahan organik yang digunakan oleh mikrobia rumen maka akan semakin tinggi pula gas yang dihasilkan. Prihartini et al. (2007) menyatakan bahwa produksi gas menunjukkan aktivitas mikrobia rumen dalam mendegradasi pakan.

Produksi gas pada inkubasi jam ke-72 pada inokulasi L. plantarum (KLp) lebih rendah dibandingkan silase kontrol tanpa inokulan (KO). Produksi gas silase pada inokulasi L. plantarum (KLp) dipengaruhi oleh jumlah fraksi pakan optimum terdegradasi yang lebih rendah $(\mathrm{P}<0,05)$ dibandingkan silase kontrol (K0). Min et al. (2005) menyatakan bahwa produksi gas yang tinggi menujukkan aktivitas mikroorganisme dan kaya nutrisi dalam rumen. Produksi gas semakin cepat mencapai puncak bila fraksi yang larut dan mudah terdegradasi semakin banyak. Muck et al. (2007) menyatakan bahwa penggunaan $L$. plantarum pada silase alfalfa memiliki hasil produksi gas total yang selalu rendah dibandingkan dengan kontrol.

Silase KBK pada inokulasi L. plantarum (KLp) memiliki fraksi $a+b$ lebih rendah $(P<0,05)$ dibandingkan silase tanpa inokulan (KO). Hal ini berbeda dengan hasil yang dilaporkan oleh Sofyan (2011) yang menyatakan bahwa penggunaan $L$. plantarum pada silase rumput raja memiliki fraksi $a+b$ yang lebih tinggi dibandingkan silase kontrol tanpa inokulan.

Silase KBK pada inokulasi $S$. cerevisiae (KSc) maupun campuran $L$. plantarum dan S. cerevisiae (KLp+Sc) memiliki nilai fraksi pakan terdegradasi optimum lebih tinggi dibandingkan silase pada

Tabel 1. Komposisi kimia silase kulit buah kakao ditambah gaplek sebagai kontrol $(K)$, kontrol $+L$. plantarum $(\mathrm{KLp})$, kontrol + S. cerevisiae $(\mathrm{KSc})$, kontrol + L. plantarum $+S$. cerevisiae $(\mathrm{KLp}+\mathrm{Sc})$ (chemical composition of silage of cocoa pod + cassava meal without inoculant as control (KO), control +

L. plantarum $(K L p)$, control $+S$. cerevisiae $(K S c)$, control $+L$. plantarum $+S$. cerevisiae $(K L p+S c)$

\begin{tabular}{|c|c|c|c|c|}
\hline \multirow{2}{*}{ Parameter* } & \multicolumn{4}{|c|}{ Silase (silage) } \\
\hline & KO & KLp & KSc & $\mathrm{KLp}+\mathrm{Sc}$ \\
\hline Bahan kering (dry matter) & $20,38 \pm 0,340^{a}$ & $22,20 \pm 1,312^{\mathrm{bc}}$ & $21,12 \pm 0,045^{\mathrm{ab}}$ & $22,66 \pm 0,489^{c}$ \\
\hline Bahan organik (organic matter) & $93,72 \pm 0,244^{a}$ & $93,82 \pm 0,105^{a b}$ & $94,27 \pm 0,310^{\mathrm{bc}}$ & $94,43 \pm 0,261^{c}$ \\
\hline Serat kasar (crude fiber) & $18,92 \pm 0,785$ & $18,16 \pm 0,375$ & $17,51 \pm 1,765$ & $15,83 \pm 1,651$ \\
\hline Protein kasar (crude protein) & $3,41 \pm 0,094$ & $3,50 \pm 0,440$ & $3,21 \pm 0,197$ & $2,99 \pm 0,141$ \\
\hline Ekstrak eter (extract ether) & $0,87 \pm 0,159^{c}$ & $0,71 \pm 0,351^{b c}$ & $0,33 \pm 0,230^{a b}$ & $0,15 \pm 0,090^{a}$ \\
\hline $\begin{array}{l}\text { Bahan ekstrak tanpa nitrogen } \\
\text { (nitrogen free extract) }\end{array}$ & $70,51 \pm 1,036^{a}$ & $71,45 \pm 0,388^{a}$ & $73,22 \pm 2,060^{\mathrm{ab}}$ & $75,46 \pm 1,688^{b}$ \\
\hline Neutral detergent fiber (NDF) & $46,37 \pm 1,395^{b}$ & $45,72 \pm 1,660^{\mathrm{b}}$ & $41,71 \pm 4,666^{\mathrm{ab}}$ & $36,84 \pm 4,716^{a}$ \\
\hline Acid detergent fiber (ADF) & $30,07 \pm 1,177^{b}$ & $28,99 \pm 1,113^{b}$ & $27,22 \pm 1,559^{b}$ & $23,48 \pm 1,896^{a}$ \\
\hline
\end{tabular}


Tabel 2. Produksi gas, fraksi pakan, laju degradasi, dan degradasi silase kulit buah kakao ditambah gaplek sebagai kontrol $(\mathrm{K})$, kontrol $+L$. plantarum $(\mathrm{KLp})$, kontrol $+S$. cerevisiae $(\mathrm{KSc})$, kontrol $+L$. plantarum $+S$. cerevisiae $(\mathrm{KLp}+\mathrm{Sc})$

(gas production, feed fraction, degradation rate, and degradation theory on silage of cocoa pod + cassava meal without inoculant as control $(K O)$, control + L. plantarum $(K L p)$, control $+S$. cerevisiae $(K S c)$, control + L. plantarum + S. cerevisiae $(K L p+S c))$

\begin{tabular}{|c|c|c|c|c|}
\hline \multirow{2}{*}{ Parameter } & \multicolumn{4}{|c|}{ Silase (silage) } \\
\hline & KO & KLp & $\mathrm{KSc}$ & $\mathrm{KLp}+\mathrm{Sc}$ \\
\hline $\begin{array}{l}\text { Produksi gas } 72 \text { jam }(\mathrm{ml}) \text { (gas } \\
\text { production }(\mathrm{ml}) \text { ) }\end{array}$ & $50,40 \pm 1,80^{b}$ & $46,79 \pm 1,45^{a}$ & $51,70 \pm 2,15^{b}$ & $52,42 \pm 0,15^{b}$ \\
\hline $\begin{array}{l}\text { Fraksi pakan terdegradasi } \\
\text { optimum }(\mathrm{ml})(\text { feed fraction of } \\
\text { optimum degradation }(\mathrm{ml}) \text { ) }\end{array}$ & $55,77 \pm 2,707^{b}$ & $50,88 \pm 1,444^{a}$ & $55,03 \pm 2,596^{b}$ & $56,37 \pm 0,400^{b}$ \\
\hline $\begin{array}{l}\text { Laju degradasi pakan (ml/jam) } \\
\text { (degradation rate }(\mathrm{ml} / \mathrm{h})\end{array}$ & $0,07 \pm 0,002^{a}$ & $0,09 \pm 0,009^{b c}$ & $0,09 \pm 0,004^{b}$ & $0,10 \pm 0,003^{c}$ \\
\hline $\begin{array}{l}\text { Degradasi teori (\%) (degradation } \\
\text { theory (\%)) }\end{array}$ & $33,31 \pm 1,85^{a b}$ & $31,99 \pm 1,22^{a}$ & $34,68 \pm 1,004^{b}$ & $37,30 \pm 0,86^{c}$ \\
\hline
\end{tabular}

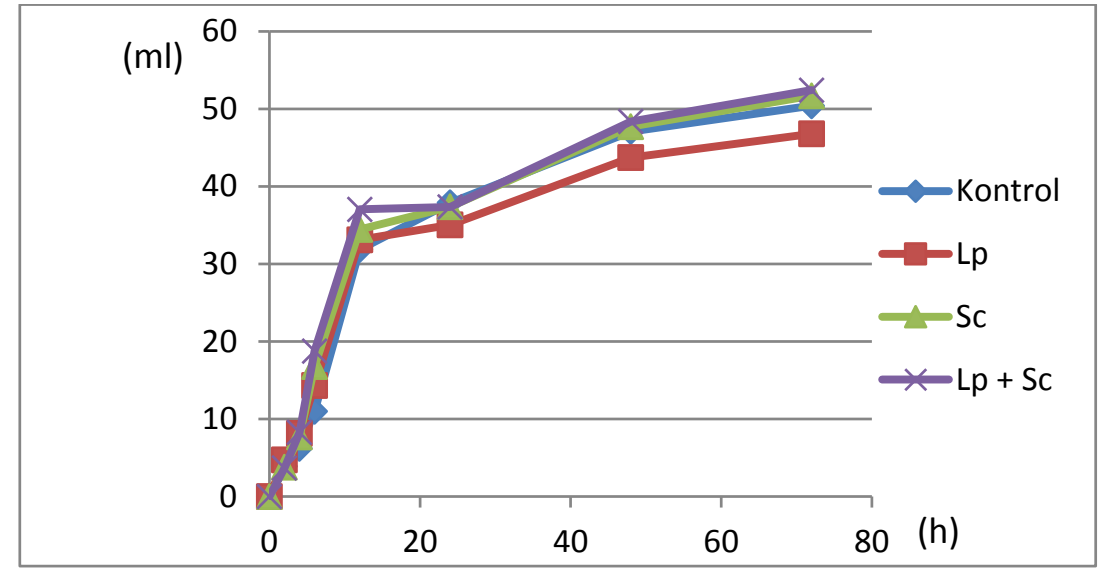

Grafik 1. Produksi gas selama 72 jam (gas production during 72 hours).

inokulasi L. plantarum (KLp). Hasil penelitian ini berbeda dengan Sofyan (2011) yang melaporkan bahwa fraksi pakan yang potensial maksimum terdegradasi pada silase rumput raja dengan penambahan bekatul sebanyak $10 \%$ dengan inkubasi selama 48 jam menggunakan $L$. plantarum secara tunggal lebih tinggi dibandingkan inokulasi campuran L. plantarum dan S. cerevisiae.

Laju degradasi adalah tingkat dimana bahan pakan tersebut dipecah (didegradasi) oleh mikroorganisme rumen dalam interval waktu inkubasi tertentu (Ismartoyo, 2011). Laju degradasi silase KBK pada inokulasi $L$. plantarum (KLp), S. cerevisiae (KSc) dan campurannya $(K L p+S c)$ lebih tinggi $(P<0,05)$ dibandingkan dengan silase KBK tanpa inokulan (KO).
Silase KBK pada inokulasi campuran $L$. plantarum dan $S$. cerevisiae (KLp+Sc) memiliki laju degradasi fraksi b lebih tinggi dibandingkan silase kontrol (KO) dan silase dengan inokulan $S$. cerevisiae (KSc). Kandungan fraksi serat silase KBK dengan inokulasi campuran $L$. plantarum dan $S$. cerevisiae menjadikan laju degradasi di dalam rumen menjadi tinggi dibandingkan perlakuan yang lain. Wati et al. (2012) menyatakan bahwa perbedaan fraksi c dipengaruhi oleh kandungan serat pada bahan pakan tersebut. Semakin tinggi kandungan dinding sel suatu bahan pakan dapat menurunkan laju degradasinya.

Laju degradasi fraksi b pada inokulasi campuran L. plantarum dan S. cerevisiae $(\mathrm{KLp}+\mathrm{Sc})$ tidak berbeda dengan laju degradasi silase KBK pada inokulasi $L$. 
plantarum (KLp), tetapi lebih tinggi $(P<0,05)$ dibandingkan dengan silase KBK pada inokulasi S. cerevisiae (KSc) dan kontrol (KO). Hasil penelitian ini berbeda dengan Sofyan (2011) yang melaporkan bahwa penggunaan inokulasi campuran L. plantarum dan S. cerevisiae dengan penambahan bekatul pada silase rumput raja yang di inkubasi selama 48 jam memiliki laju degradasi dari fraksi b yang tidak berbeda nyata dengan silase kontrol dan L. plantarum secara tunggal. Orskov dan Ryle (1990) menyatakan bahwa fraksi c akan rendah pada pakan yang mengandung selulosa yang tinggi, pakan dengan serat kasar yang rendah akan mudah dicerna dan memerlukan waktu yang pendek per satuan berat.

Degradasi teori adalah degradasi yang efektif terjadi di dalam rumen dari suatu bahan pakan pada jam inkubasi tertentu. Silase KBK pada inokulasi campuran $L$. plantarum dan $S$. cerevisiae $(\mathrm{KLp}+\mathrm{Sc})$ menunjukkan perbedaan yang nyata dibandingkan dengan silase control (KO) dan perlakuan yang lain (KLp dan $\mathrm{KSc})$. Hal ini karena laju degradasi silase KBK pada inokulasi campuran $L$. plantarum dan $S$. cerevisiae $(K L p)$ lebih tinggi dibandingkan silase kontrol (KO) dan perlakuan yang lain (KLp dan KSc) dengan fraksi potensial maksimum terdegradasi $(a+b)$ yang tidak nyata. Degradasi pakan dipengaruhi oleh laju degradasi dan fraksi potensial maksimum terdegradasi, laju degradasi silase KBK pada inokulasi campuran L. plantarum dan $S$. cerevisiae $(\mathrm{KLp}+\mathrm{Sc})$ memiliki nilai tertinggi mempengaruhi degradasi teori silase KBK. Orskov (1992), menyatakan bahwa kelarutan bahan pakan, laju degradasi di dalam rumen, tingkat konsumsi, ketersediaan substrat terfermentasi, ukuran partikel, populasi mikrobia, bentuk fisik pakan, dan $\mathrm{pH}$ rumen dapat mempengaruhi degradasi pakan di dalam rumen.

\section{Parameter fermentasi rumen}

Hasil uji $\mathrm{pH}$, kadar amonia, volatile fatty acid, dan protein mikrobia rumen silase KBK dengan penambahan dan tanpa inokulan tersaji pada Tabel 3.

Silase KBK pada inokulasi $S$. cerevisiae (KSc), maupun campuran $L$. plantarum dan $S$. cerevisiae $(\mathrm{KLp}+\mathrm{Sc})$ memiliki $\mathrm{pH}$ yang lebih rendah $(\mathrm{P}<0,05)$ dibandingkan dengan silase pada inokulasi $L$. plantarum (KLp) dan kontrol (KO). Secara umum, inokulasi $S$. cerevisiae (KSc) maupun campuran $L$. plantarum dan $S$. cerevisiae $(\mathrm{KLp}+\mathrm{Sc})$ menjadikan $\mathrm{pH}$ rumen menjadi lebih rendah dibandingkan perlakuan lain. Derajat keasaman rumen yang dihasilkan oleh silase KBK cukup rendah, tetapi masih dalam kisaran normal. Faktor kandungan BETN silase KBK yang cukup memiliki pengaruh pada derajat keasaman $(\mathrm{pH})$ rumen. Kandungan BETN silase dengan inokulasi campuran L. plantarum dan S. cerevisiae $(\mathrm{KLp}+\mathrm{Sc})$ yang lebih tinggi dibandingkan kontrol (KO) dan perlakuan lain (KLp dan KSc) menjadikan derajat keasaman $(\mathrm{pH})$ rumen terendah. Utomo (2001) menyatakan bahwa derajat keasaman $(\mathrm{pH})$ rumen antara lain dipengaruhi oleh jenis pakan yang dimakan terutama karbohidrat non-struktural, bahan pakan yang banyak mengandung karbohidrat non-struktural akan cepat menurunkan $\mathrm{pH}$ cairan rumen.

Hasil penelitian menunjukkan bahwa penggunaan silase memiliki nilai $\mathrm{pH}$ pada kisaran normal yaitu sekitar 6-7 (Van Soest, 1994; Sung et al., 2007). Laconi (2009) melaporkan bahwa $\mathrm{pH}$ cairan rumen dengan adanya silase KBK tanpa penambahan inokulan sekitar 6,21. Laconi (2009) juga melaporkan bahwa silase dengan penambahan cairan rumen sebagai silage additive sekitar 6,15, dan KBK fermentasi dengan penambahan $P$. chyrosporium sekitar 6,38 .

Perlakuan penambahan aditif tidak mempengaruhi kadar amonia (NH3) cairan rumen dari pakan silase KBK. Hal ini sesuai dengan hasil penelitian Wahjuni et al. (2010) yang menunjukkan bahwa inokulasi campuran L. plantarum dan S. cerevisiae pada silase rumput gajah dan jerami padi yang dicampur konsentrat dan tetes tidak memiliki perbedaan terhadap kadar amonia nitrogen cairan rumen. Hal ini berbeda dengan hasil penelitian Laconi (2009) yang melaporkan bahwa kandungan amonia $\left(\mathrm{NH}_{3}\right)$ hasil fermentasi rumen silase KBK memilki perbedaan yang nyata, silase KBK tanpa penambahan inokulan sekitar $7,11 \mathrm{mg} / 100$ $\mathrm{ml}$, silase dengan penambahan cairan rumen sebagai bahan aditif silase sekitar 7,62 $\mathrm{mg} / 100 \mathrm{ml}$, serta KBK fermentasi dengan penambahan $P$. chyrosporium sekitar 10,04 $\mathrm{mg} / 100 \mathrm{ml}$. Ningrat dan Khasrad (2012) melaporkan bahwa KBK yang terfermentasi di dalam rumen memiliki kandungan amonia sekitar 29,60 mg/100 ml. 
Tabel 3. Parameter fermentasi di dalam rumen dengan pemberian silase kulit buah kakao ditambah gaplek sebagai kontrol $(K)$, kontrol $+L$. plantarum $(K L p)$, kontrol $+S$. cerevisiae $(K S c)$, kontrol $+L$. plantarum $+S$. cerevisiae $(\mathrm{KLp}+\mathrm{Sc})$

(paramters ruminal fermentation on silage of cocoa pod + cassava meal without inoculant as control (KO), control + L. plantarum $(K L p)$, control + S. cerevisiae $(K S c)$, control + L. plantarum + S. cerevisiae $(K L p+S c))$

\begin{tabular}{|c|c|c|c|c|}
\hline \multirow{2}{*}{ Parameter } & \multicolumn{4}{|c|}{ Silase (silage) } \\
\hline & K0 & KLp & KSc & $\mathrm{KLp}+\mathrm{Sc}$ \\
\hline $\mathrm{pH}(p H)$ & $6,69 \pm 0,04^{b}$ & $6,63 \pm 0,04^{b}$ & $6,39 \pm 0,03^{a}$ & $6,34 \pm 0,04^{a}$ \\
\hline $\mathrm{NH}_{3}(\mathrm{mg} / 100 \mathrm{ml})\left(\mathrm{NH}_{3}(\mathrm{mg} / 100 \mathrm{ml})\right)^{\mathrm{ns}}$ & $23,50 \pm 1,43$ & $21,31 \pm 3,52$ & $19,37 \pm 4,22$ & $20,21 \pm 0,37$ \\
\hline Asetat $(\mathrm{mM} / \mathrm{L})(\text { acetate }(m M / L))^{\mathrm{ns}}$ & $48,52 \pm 1,75$ & $43,60 \pm 3,54$ & $45,91 \pm 6,05$ & $49,11 \pm 4,25$ \\
\hline Propionat $(\mathrm{mM} / \mathrm{L})(\text { propionate }(m M / L))^{\mathrm{ns}}$ & $20,56 \pm 0,93$ & $18,53 \pm 2,73$ & $16,84 \pm 2,05$ & $18,92 \pm 1,60$ \\
\hline Butirat $(\mathrm{mM} / \mathrm{L})$ (butyric $(m M / L))$ & $8,48 \pm 0,64^{a}$ & $8,76 \pm 0,58^{a}$ & $10,70 \pm 0,45^{b}$ & $10,80 \pm 0,51^{b}$ \\
\hline Asetat (\%) (acetate (\%)) $)^{\mathrm{ns}}$ & $62,55 \pm 1,88$ & $61,54 \pm 0,64$ & $62,48 \pm 0,54$ & $62,26 \pm 0,92$ \\
\hline Propionat (\%) (propionate (\%)) & $26,52 \pm 1,30^{c}$ & $26,05 \pm 1,16^{\mathrm{bc}}$ & $22,94 \pm 0,31^{\mathrm{a}}$ & $24,00 \pm 0,93^{\mathrm{ab}}$ \\
\hline Butirat (\%) (butyric (\%)) & $10,93 \pm 0,70^{a}$ & $12,40 \pm 1,08^{b}$ & $14,57 \pm 0,32^{c}$ & $13,70 \pm 0,40^{\text {bc }}$ \\
\hline $\begin{array}{l}\text { Rasio asetat: propionat (ratio acetate : } \\
\text { propionate) }\end{array}$ & $2,37 \pm 0,19^{a}$ & $2,37 \pm 0,17^{a}$ & $2,73 \pm 0,60^{b}$ & $2,60 \pm 0,14^{\mathrm{ab}}$ \\
\hline $\begin{array}{l}\text { Protein mikrobia }(\mathrm{mg} / \mathrm{ml})(\text { microbial } \\
\text { protein }(\mathrm{mg} / \mathrm{ml}))^{\mathrm{ns}}\end{array}$ & $0,23 \pm 0,05$ & $0,26 \pm 0,05$ & $0,27 \pm 0,02$ & $0,32 \pm 0,03$ \\
\hline
\end{tabular}

Keberadaan amonia di dalam rumen merupakan indikasi terjadinya degradasi protein. Protein akan didegradasi menjadi oligopeptide. Protein kemudian didegradasi menjadi peptida dan asam amino. Proses deaminasi asam amino menghasilkan amonia. Protein yang terdegradasi di dalam rumen merupakan sumber nitrogen untuk mikrobia rumen menghasilkan protein mikrobia. Hasil penilitian menujukan bahwa kadar amonia di dalam rumen dengan adanya silase KBK sekitar 19 hingga 23 mg/100 mL berada pada kisaran normal. Hal ini sesuai dengan pendapat Harfiah (2006) yang menyatakan bahwa secara normal aktivitas mikroorganisme memerlukan konsentrasi amonia sebesar 8,5-30 mg/100 mL. Arifin dan Zulfanita (2012) menyatakan bahwa kadar amonia $50 \mathrm{mg} / 100 \mathrm{~mL}$ di dalam rumen cukup untuk memenuhi kebutuhan sintesis protein mikroba rumen secara optimal. Orskov (1992) menyatakan bahwa kadar amonia kurang dari 50 mg/L merupakan kadar efektif sehingga kinerja mikrobia rumen dapat melakukan aktivitasnya. McDonald et al. (2002) menyatakan bahwa kisaran normal konsentrasi $\mathrm{N}-\mathrm{NH}_{3}$ untuk menunjang pertumbuhan mikrobia rumen yaitu sekitar 10,21$35,76 \mathrm{mg} / 100 \mathrm{ml}$.

Hasil penelitian menunjukkan bahwa silase KBK pada inokulasi campuran $L$. plantarum dan $S$. cerevisiae $(\mathrm{KLp}+\mathrm{Sc})$ memiliki kandungan asam butirat tertinggi $(\mathrm{P}<0,05)$ dibandingkan kontrol (K0) dan perlakuan yang lain (KLp dan KSc). Hasil penelitian ini berbeda dengan hasil penelitian Sofyan (2011) yang menunjukkan bahwa inokulasi L. plantarum dengan penambahan bekatul sebanyak 10\% pada silase rumput raja yang diinkubasi selama 48 jam memiliki kadar VFA (asam asetat 101,03 mM, propionat $32,45 \mathrm{mM}$, butirat $12,11 \mathrm{mM}$ ). Kadar VFA tersebut lebih tinggi dibandingkan silase pada inokulasi campuran L. plantarum dan S. cerevisiae (kadar asam asetat 71,65 mM, propionat $27,99 \mathrm{mM}$, butirat $9,73 \mathrm{mM}$ ).

Tingginya kandungan asam butirat pada cairan rumen silase KBK pada inokulasi campuran L. plantarum dan S. cerevisiaae $(\mathrm{KLp}+\mathrm{Sc})$ dibanding silase pada inokulasi $L$. plantarum (KLp) dan silase kontrol (KO) menunjukkan bahwa aktivitas bakteri amilolitik di dalam rumen cukup tinggi. Kandungan VFA dari fermentasi rumen akan berbeda, jika terdapat perbedaan rasio antara karbohidrat terlarut dengan neutral detergent fiber (NDF). Sveinbjornsson et al. (2006) menyatakan bahwa perbedaan level proporsi antara NDF dengan karbohidrat terlarut dapat mempengaruhi kandungan VFA.

Hasil analisis proporsi molar VFA pada cairan rumen silase KBK menunjukkan bahwa 
proporsi molar asam asetat memiliki perbedaan yang tidak nyata $(P>0,05)$, hal ini menunjukkan bahwa tidak terdapat pengaruh inokulasi terhadap proporsi asetat di dalam rumen. Kandungan fraksi serat yang rendah dan ETN yang cukup tinggi pada silase KBK inokulasi campuran $L$. plantarum dan $S$. cerevisiae $(\mathrm{KLp}+\mathrm{Sc})$ dibandingkan silase $\mathrm{KBK}$ kontrol (KO) dan perlakuan yang lain (KLp dan $\mathrm{KSc}$ ), hal tersebut tidak mempengaruhi proporsi asam asetat di dalam rumen. Hal ini berbeda dengan Utomo (2001) yang menyatakan bahwa kenaikan kandungan karbohidrat nonstruktural akan menurunkan kandungan asetat di dalam rumen.

Proporsi propionat antar perlakuan menunjukkan perbedaan yang nyata $(P<0,05)$. Silase pada inokulasi $S$. cerevisiae (KSc) memiliki proporsi molar propionat terendah dibandingkan silase kontrol (K0) dan silase L. plantarum (KLp). Silase kontrol (KO) memiliki proporsi molar propionat tertinggi yaitu $26,52 \pm 1,30$ tetapi tidak berbeda nyata dengan silase dengan penambahan $L$. plantarum (KLp). Mujnisa (2007) menyatakan bahwa proporsi molar propionat kulit buah kakao di dalam rumen sekitar 34,1\%.

Proporsi molar butirat antar perlakuan menunjukkan perbedaan yang nyata $(P<0,05)$. Proporsi molar butirat diurut dari terendah ke tinggi yaitu silase kontrol (K0), silase pada inokulasi L. plantarum (KLp), silase pada inokulasi campuran L. plantarum dan S. cerevisiae (KLp+Sc). Hasil kajian proporsi molar butirat yang dihasilkan dari fermentasi silase KBK di dalam rumen menunjukkan dengan adanya inokulasi dapat meningkat proporsi molar butirat. Jenis inokulan yang ditambahkan pada silase KBK berpengaruh pada proporsi molar butirat. Penambahan $\mathrm{S}$. cerevisiae (KSc) ataupun kombinasi (KLp+Sc) dapat meningkatkan persentase molar butirat.

Rasio asetat : propionat menunjukkan perbedaan yang nyata $(P<0,05)$. Silase pada inokulasi $S$. cerevisiae (KSc) memiliki nilai rasio asetat : propionat tertinggi yaitu 2,73 \pm 0,60 , tetapi tidak berbeda nyata terhadap silase KBK pada inokulasi campuran $L$. plantarum dan S. cerevisiae (KLp+Sc). Hal ini menunjukkan bahwa proporsi asetat dibandingkan propionat yang dihasilkan oleh silase KBK pada inokulasi S. cerevisiae (KSc) cukup tinggi dibandingkan dengan silase $\mathrm{KBK}$ yang lain ( $\mathrm{KO}, \mathrm{KLp}$, dan $\mathrm{KLp}+\mathrm{Sc}$ ). Proporsi asetat yang lebih tinggi dibandingkan propionat menujukkan bahwa degradasi SK di dalam rumen cukup tinggi. Pakan yang mengandung SK di dalam rumen akan didegradasi oleh mikrobia rumen menjadi asam asetat.

Protein mikrobia rumen antar perlakuan menunjukkan perbedaan yang tidak nyata $(P>0,05)$. Hal ini disebabkan karena tidak selarasnya ketersediaan kerangka karbon dan nitrogen, kandungan PK yang rendah menjadikan sumber nitrogen yang rendah di dalam rumen. Sumber nitrogen akan digunakan oleh mikrobia rumen untuk dijadikan senyawa protein mikrobia. Protein mikrobia sangat dipengaruhi oleh degradasi karbohidrat dan protein. Degradasi karbohidrat menghasilkan kerangka karbon sedangkan hasil degradasi protein menghasilkan gugus amina. Kerangka karbon selain diperoleh dari karbohidrat, tetapi dapat berasal dari protein dan lipid pula. Fermentasi karbohidrat menghasilkan energi, ketersediaan energi menjadi salah satu faktor yang dapat mempengaruhi kadar protein mikrobia. Widyobroto et al. (2007) menyatakan bahwa efisiensi pertumbuhan dan produksi protein mikrobia dapat ditingkatkan dengan adanya keseimbangan antara energi dan nitrogen yang terdian di dalam pakan, perbaikan sinkronisasi energi dan protein yang dibebaskan dalam rumen dapat meningkatkan sintesis protein mikrobia.

Kecernaan in vitro silase kulit buah kakao. Hasil uji kecernaan in vitro silase KBK dengan penambahan dan tanpa inokulan tersaji pada Tabel 4.

Kecernaan BK silase KBK antar perlakuan menunjukkan perbedaan yang tidak nyata $(P>0,05)$. Kecernaan $B K$ silase KBK dipengaruhi oleh kandungan SK, kandungan SK yang memiliki perbedaan yang tidak nyata menjadikan kecernaan BK memiliki perbedaan yang tidak nyata antar perlakuan. Imsya dan Palupi (2009) menyatakan bahwa semakin rendah kandungan NDF, ADF, dan lignin dalam suatu bahan pakan maka akan meningkatkan nilai kecernaan.

Kandungan lignin yang cukup tinggi dalam SK dapat menghambat degradasi BK di dalam rumen, hemiselulosa dan selulosa yang terikat cukup kuat pada lignin dapat menurunkan kecernaan BK silase KBK. Puastuti et al. (2008) menyatakan bahwa ikatan lignin pada KBK tidak peka terhadap 
Tabel 4. Kecernaan in vitro BK dan BO silase KBK silase kulit buah kakao ditambah gaplek sebagai kontrol $(\mathrm{K})$, kontrol + L. plantarum $(\mathrm{KLp})$, kontrol + S. cerevisiae $(\mathrm{KSc})$, kontrol + L. plantarum $+S$. cerevisiae $(\mathrm{KLp}+\mathrm{Sc})$

(in vitro digestibility DM and OM on silage of cocoa pod + cassava meal without inoculant as control (KO), control + L. plantarum $(K L p)$, control + S. cerevisiae $(K S c)$, control + L. plantarum $+S$. cerevisiae $(K L p+S c))$

\begin{tabular}{lcccc}
\hline \hline \multicolumn{1}{c}{ Parameter* } & \multicolumn{4}{c}{ Silase (silage) } \\
\cline { 2 - 5 } & K0 & KLp & KSc & KLp + Sc \\
\hline $\begin{array}{l}\text { Kecernaan bahan kering (in vitro } \\
\text { digestibility dry matter) }\end{array}$ & $72,85 \pm 1,52$ & $73,72 \pm 0,84$ & $75,06 \pm 1,69$ & $76,26 \pm 2,51$ \\
$\begin{array}{l}\text { Kecernaan bahan organik (in vitro } \\
\text { digestibility organic matter) }\end{array}$ & $61,00 \pm 1,58$ & $62,25 \pm 1,16$ & $62,37 \pm 1,61$ & $63,03 \pm 1,82$ \\
\hline $\begin{array}{l}* \quad \text { Persentase bahan kering (percentage dry matter). } \\
\text { ns } \text { Tidak berbeda nyata (non significant different). }\end{array}$ & & & \\
\hline
\end{tabular}

amoniasi, diduga karena KBK mengandung ester yang rendah dan gugus methoxyl yang lebih tinggi dibandingkan dengan rumputrumputan. Jung et al. (1996) menyatakan bahwa ternak ruminansia dapat mencerna 40$70 \%$ BK di dalam dinding sel, nilai ini sangat bervariasi $20-40 \%$ untuk tanaman leguminosa dan $50-80 \%$ untuk tanaman rumputrumputan. Toharmat et al. (2006) melaporkan bahwa ransum yang mengandung 49,02\% kulit coklat, memiliki kecernaan bahan kering sebesar 54,5\%.

Kecernaan $\mathrm{BO}$ silase $\mathrm{KBK}$ antar perlakuan menunjukkan perbedaan yang tidak nyata $(P>0,05)$. Inokulasi $L$. plantarum dan $S$. cerevisiae tidak memiliki pengaruh terhadap kecernaan BO. Perubahan kandungan BETN dengan adanya penggunaan inokulum pada silase KBK belum dapat mempengaruhi kecernaan BO. Kecernaan BO yang tidak nyata antar perlakuan mengikuti kecernaan BK yang tidak nyata, hal ini karena $\mathrm{BO}$ adalah bagian dari BK. Kecernaan BO silase KBK yang tidak nyata dipengaruhi oleh kandungan SK yang tidak nyata. Kandungan SK merupakan faktor pembatas kualitas sebuah bahan pakan, semakin rendah SK suatu bahan pakan akan meningkatkan kecernaan bahan pakan tersebut. Van Soest (1994) menyatakan bahwa fraksi serat pada suatu bahan pakan mengandung lignin yang menjadi faktor penghambat dalam proses kecernaan BO.

\section{Kesimpulan}

Hasil penelitian menunjukkan bahwa inokulasi campuran L. Plantarum dan $S$. Cerevisiae pada silase $\mathrm{KBK}$ berpengaruh pada laju degradasi fraksi pakan dan degradasi teori di dalam rumen, namun tidak memberikan pengaruh terhadap kecernaan in vitro, sehingga silase KBK tanpa inokulasi $L$. Plantarum dan S. Cerevisiae memiliki kualitas yang cukup sebagai pakan berserat ternak ruminansia.

\section{Daftar Pustaka}

Arifin, H. D. dan Zulfanita. 2012. Amonia rumen dan urea darah kambing jawarandu pengaruh pemberian daun pepaya. Surya Agritama 1: 38-47.

Astuti, M. 2007. Pengantar IImu Statistik untuk Peternakan dan Kesehatan Hewan. Cetakan Pertama. Binasti Publisher, Bogor.

Harfiah. 2006. Perbandingan daya cerna in vitro bahan kering rumput gajah dan hasil fermentasi campuran rumput lapangan dengan isi rumen. Jurnal Sains dan Ethiologi 6: 67-70.

Imsya, A. dan R. Palupi. 2009. Perubahan kandungan lignin, neutral detergent fiber, dan acid detergent fiber pelepah sawit melalui proses biodegumming sebagai sumber bahan pakan berserat ternak ruminansia. Jurnal IImu Ternak dan Veteriner 14: 284-287.

Ismartoyo. 2011. Pengantar Teknik Penelitian Degradasi Pakan Ternak Ruminansia. Brilian Internasional, Surabaya.

Jung, H. D., D. Buxton, R. hatflied, D. Mertens, J. Ralph, and P. Wermer. 1996. Improving forage fibre difetibility. Feedmix 4: 30-33.

Laconi, E. B. 2009. The evaluation of rumen metabolism of Fries Holstein (FH) calves fed biofermented cocoa pods using Phanerochaeta chrysosporium. The 1st International Seminar on Animal Industry 2009 at Faculty of Animal Science, Bogor Agricultural University, Bogor. 
McDonald, P., R. A. Edwards, J. F. D. Greenhalgh and C. A. Morgan. 2002. Animal Nutrition. Prentice Hall, London.

Min, B. R., W. E. Pinchak, J. D. Fulford and R. Puchala. 2005. Wheat pasture bloat dynamics in-vitro ruminal gas production and potensial bloat mitigation with condensed tannins. J. Anim. Sci. 83: 1322-1331.

Muck, R. E. I. Fillyaa and F. E. ContrerasGovea. 2007. Inoculant effect on alfalfa silage; in vitro gas and volatile fatty acid production. J. Dairy Sci. 90: 5115-5125.

Mujnisa, A. 2007. Kecernaan bahan kering in vitro, proporsi molar asam lemak terbang dan produksi gas pada kulit kakao, biji kapuk, kulit markisa dan biji markisa. Buletin Nutrisi dan Makanan Ternak 6: 31-36.

Ningrat, R. W. S. and Khasrad. 2012. Effect of waste products on ruminal, icrobe population and rumen characteristics in vitro. Prceeding of the $2^{\text {nd }}$ International Seminar on Animal Industry, Jakarta.

Orskov, E. R. 1992. Protein Nutrition in Ruminant. Academic Press, London.

Orskov, E. R. and M. Ryle. 1990. Energy Nutrition in Ruminant. Elsevier App Sci, London.

Prihartini, I., S. Chuzaemi, dan O. Sofjan. 2007. Parameter fermentasi rumen dan produksi gas in vitro jerami padi hasil fermentasi inokulum lignochloritik. Jurnal Protein 15: 24-32.

Puastuti, W., D. Yulistiani, dan Supriyati. 2008. Ransum berbasis kulit buah kakao diperkaya mineral: tinjauan pada kecernaan dan fermentasi rumen in vitro. Proceeding Seminar Nasional Teknologi Peternakan dan Veteriner.

Sofyan, A. 2011. Efektivitas inokulum bakteri asam laktat dan khamir dari isolat alami dengan penambahan dedak padi terhadap kualitas silase rumput raja (Pennisetum hybrid). Tesis Fakultas Peternakan, Universitas Gadjah Mada, Yogyakarta.

Soleh, A. Z. 2005. Ilmu Statistika Pendekatan Teoritis dan Aplikatif disertai Contoh Penggunaan SPSS. Penerbit Rakayasa Sains, Bandung.

Sung, H. G., Y. Kobayashi, J. Chang, A. Ha, I. H. Wang and J. K. Ha. 2007. Low ruminal $\mathrm{pH}$ reduce dietary fiber digestion reduced microbial attachment. Asian-Aust. J. Anim. Sci. 20: 200-207.

Sveinbjornsson, J., M. Murphy and P. Uden. 2006. Effect of the proportion of neutral detergent fiber and starch, and their degradation rates, on in vitro ruminal fermentation. J. Anim. Feed Sci. Technol. 130: 172-190.

Toharmat, T., E. Nursasih, R. Nazilah, N. Hotimah, T. Q. Noerzihad, N. A. Sigit, dan Y. Retnani. 2006. Sifat fisik pakan kaya serat dan pengaruhnya terhadap konsumsi dan kecernaan nutrien ransum kambing. Media Peternakan 29: 146-157.

Utomo, R. 2001. Penggunaan jerami padi sebagai pakan basal: suplementasi sumber energi dan protein terhadap transit partikel pakan, sintesis protein mikrobia, kecernaan, dan kinerja sapi potong. Disertasi Fakultas Peternakan, Universitas Gadjah Mada, Yogyakarta.

Van Soest, P. J. 1994. Nutritional Ecology of The Ruminant. Cornell University Press, London.

Wahjuni, R. S., R. Bijanti, dan R. Sidik. 2010. Produk metabolit cairan rumen domba yang diberi starter bakteri asam laktat dan yeast pada rumput gajah dan jerami padi. Veterinaria Medika 3: 3540.

Wati, N. E., J. Achmadi, dan E. Pangestu. 2012. Degradasi nutrien bahan pakan limbah pertanian dalam rumen kambing secara in sacco. Anim. Agr. J. 1: 485498.

Widyobroto, B. P., S. P. S. Budhi, dan A. Agus. 2007. Pengaruh aras undegraded protein dan energi terhadap kinetika fermentasi rumen dan sintesis protein mikroba pada sapi. J. Indon. Trop. Anim. Agric. 32: 194200.

Zain, M. 2009. Substitusi rumput lapangan dengan kulit buah coklat amoniasi dalam ransum domba lokal. Jurnal Medis Peternakan 32: 47-52. 